\title{
THE IMPACT OF GLOBALIZATION ON THE SLOVAK HOTEL INDUSTRY
}

\author{
[Vplyv globalizácie na slovenské hotelierstvo] \\ Marian Gúčik ${ }^{1}$, Matúš Marcišs ${ }^{2}$ \\ ${ }^{1}$ Univerzita Mateja Bela, Ekonomická fakulta, Tajovského 10, 97590 Banská Bystrica \\ Email: marian.gucik@umb.sk \\ ${ }^{2}$ Univerzita Mateja Bela, Ekonomická fakulta, Tajovského 10, 97590 Banská Bystrica \\ Email:matus.marcis@umb.sk
}

\begin{abstract}
Among the various sectors that drive the global economy, the tourism is one of the fastest growing, accounting for nearly one-third of the global services trade, one-tenth of global GDP, and onetenth of all jobs. The accommodation facilities, their size, capacity and structure are a precondition for the development of tourism. The purpose of the paper is to examine changes in Slovak accommodation sector in the process of globalization. The article deals with the changes in structure and performances of the accommodation sector in 2000, 2008 and 2016. It points out the impact of globalization on the Slovak hotel industry.
\end{abstract}

Keywords: accommodation facilities, globalization, hotel industry, Slovak Republic.

JEL classification: L83, M10

Doručeno redakci: 2.5.2018; Recenzováno: 25.5.2018; 15.9.2018; Schváleno k publikování: 21.11.2018

\section{Introduction}

In Slovakia, there have been significant changes in the structure of accommodation sector. These changes relate to the number of facilities and their qualitative structure as well. This is the result of globalization trends, the introduction of modern technologies and the growing concentration. The global economic crises have also noteworthy impacts. W. Alejziak (2007) noted two groups of factors, which influence tourism in the 21st century, the so-called external factors referred to the megatrends and internal factors associated with the market of tourism. The basis for success in the hotel industry is the permanent monitoring of demand trends and fast reaction to them.

\section{Globalization and tourism}

At the end of the 20th of the century, the tourism began to show the impact of technical and technological changes, changes in the employment and lifestyle and the globalisation of socioeconomic life. The Organisation for Economic Co-operation and Development (OECD) characterised globalisation as a process in which markets and production in different countries are becoming more dependent (Horská, Ubrežiová 2001, p. 162). Globalisation, however, is not a new process. The appearances of globalisation can be observed regarding the great geographical discoveries in the world and the overseas activities of commercial companies in the 16th century, in the expansion of the European states on the other continent (A. Zorska In Nawrocka, Oparka 2007, p. 17).

The different understandings of globalization are highlighted by Sirůček and Heczko (2006), who distinguish between technical, economic, social and political globalization. It exceeds the 
boundaries of the individual states, which are integrated into the world economy. Tourism and globalization are mutually determining. Tourism has become a major driver of globalization. It can be said that travelling and visiting other countries affecting the way of life and work of the population for centuries. M. A. Hjalagerová (2007) described tourism as a hyper-globalization factor, which requires the development of appropriate policies and strategies.

In tourism, globalization is connected with both the demand and supply (sources). The minor impact of globalisation is on the natural and historical sources. These are part of the tourism product (package) and characterized as the natural, cultural and social particularities of individual countries or regions (Nowakowska 2006). The main influences of globalization on tourism sources are (Smeral 1998; Gúčik 1999, 2009; Gúčik, Vetráková 2013):

- the establishment of new tourism destinations (tourism resorts, regions, countries), which development is supported by the investment in the tourism infrastructure and local infrastructure, it creates changes in the tourism market (the European, East Asian and the US market have $90 \%$ share in international tourism);

- the homogenous and unified high quality branded products (innovations, creating a global brand and a strong image), the competition pushing small and medium-sized enterprises out of the market as a result of lower costs;

- the use of information and communication technologies in the management of tourism, the concentration of multinational companies in the global tourism market, which may satisfy a significant part of the international demand, the use of electronic systems of booking and the internet;

- the entrance of multinational companies (airlines, hotel chains, tour operators, etc.) into the domestic market, the expansion of small enterprises across borders (foreign branches, investment abroad - capital movements) and changes in organisational structures, joint ventures, strategic partnerships, fusions to reduce costs and thus gain a competitive advantage. This applies not only to individual enterprises but also to the destination (tourism centres, regions);

- enterprise marketing management, interactive marketing and customer relationship management techniques (demand concentration, differentiation of supply, customer target groups specialization, cost advantage, lower prices, the creation of "tailor-made products").

Currently, the globalisation is mostly connected with the globalization of tourism markets and tourism industries (Nawrocka, Oparka 2007).

The globalisation of tourism is based on the fact that tourists (visitors, guests) are the representatives of the demand for the tourism products of other countries. This has lead to the globalization of the consumption, which is a permanent process of imitating global consumption. Its result is the creation of the so-called global consumer culture. Tourists buy not only the individual services and goods but also the brand (image). This is accompanied by trends in satisfying the needs of the visitors (Buranovský 2011; Kvasnová a Pančíková 2016). It has an impact also on other processes in the tourism industry, such as:

- the polarization of tourists' behaviour, demand for higher quality service and experience, the active spending of leisure time, health care and a healthy lifestyle, confrontation between mass tourism and alternative forms of tourism;

- progressive unification of tourism services, specialisation including architecture and equipment of buildings; 
- the use of information technologies (internet, electronic reservation systems, mobile technologies), modern technologies, the creation of the tourism enterprises networks and partnerships;

- the global policy, the implementation of the concept of eco-tourism, the implementation of the Global Code of Ethics for Tourism (UNWTO 1999) and the Code of Practical Realization of the Cooperation between Hotels and Travel Agencies (1999, before that 1991) based on the cooperation between the United Federation of Travel Agents' Associations (UFTAA) and International Hotel \& Restaurant Association (IHRA).

The impact of globalisation on tourism industry is associated with the creation of networks tourism partnership. It is a precondition for better access to the foreign markets. As a result of the growth in global competition, tourism enterprises form strategic alliances, such as airlines and travel agencies. In hotel market, it is the entry of international hotel companies - chains to national markets. Similar trends can be observed in the case of companies offering catering services. The attempt of the globalization in the internal market of the European Union is the requirement of the standards of equipment and services of hotels ${ }^{1}$. The Umbrella Association of Hotels, Restaurants, Pubs and Cafes (HOTREC) developed unified standards for the classification of hotels "Hotel Stars Union". The liberalization of tourism supports the process of globalization associated with the free movement of persons, services, capital and information. Not only within the EU but worldwide.

These processes are associated with the internationalisation of entrepreneurship and the increased importance of marketing strategies in the international market. For example, multinational hotel chains. The internationalisation in the hotel industry started earlier than in other sectors of tourism, in the 1950s. It strongly influenced the creation of hotels, their equipment and services, as well as the entrance of hotel chains in the national markets (Gúčik, Šípková 2004; Gúčik, Uličná 2014).

\section{Aim, material and methodology}

The purpose of the paper is to examine changes in Slovak accommodation sector in the process of globalization. The article is based on the views of the authors, who deals with the globalization in tourism (Smeral 1998; Gúčik 1999, 2009; Horská \& Ubrežiová 2001; Gúčik \& Šípková 2004; Nowakowska 2006; Alejziak 2007; Hjalager 2007; Nawrocka \& Oparka 2007; Gúčik \& Buranovský 2012; Gúčik \& Vetráková 2013; Gúčik \& Uličná 2014).

The attention will be paid to the development of the Slovak hotel industry and to find answers to the following questions:

(1) What changes have occurred in the structure and performance of accommodation sector before and after the global crisis (in 2000 and 2008, 2008 and 2016)?

(2) What is the product specialization in the Slovak hotel industry?

(3) How the hotel industry structure in Slovakia changed after 2000 due to the entry of multinational hotel companies?

The empirical data were acquired from the Statistical Office of the Slovak Republic (ŠÚ SR). The statistics contain the information about the performances of registered accommodation facilities. The information on multinational hotel companies were collected from their web-sites. The data

\footnotetext{
${ }^{1}$ The Services in the Internal Market Directive 2006/123/EC.
} 
were processed by selected methods of descriptive statistics, in terms of structure and dynamics of development.

\section{Results}

The article presents the structure and performance of accommodation establishments in Slovakia in 2000, 2008 and 2016. Firstly, it focused on the impact of globalization on the hotels' specialization and structure.

\subsection{Changes in the structure of accommodation sector in Slovakia}

The number and capacity of accommodation facilities in Slovakia have been developing positively. This trend was supported mainly by the business activity and progressive development of tourism in the regions (Table 1).

Table 1: Development of accommodation sector in Slovakia (structure and capacity)

\begin{tabular}{|l|r|r|r|r|c|}
\hline Indicator/ Year & \multicolumn{1}{|c|}{2000} & 2008 & 2016 & Index 2008/00 & Index 2016/08 \\
\hline Accommodation facilities (total) & 1,559 & 3,434 & 3,489 & 2.20 & 1.02 \\
Hotels & 366 & 596 & 654 & 1.63 & 1.10 \\
Rooms & 39,440 & 58,182 & 59,925 & 1.48 & 1.03 \\
Beds (total) & 102,800 & 151,991 & 152,624 & 1.48 & 1.00 \\
$\quad$ Hotels beds & 43,735 & 51,816 & 70,321 & 1.19 & 1.36 \\
\hline The share of hotels \% & 23.5 & 17.4 & 18.75 & $\mathrm{x}$ & $\mathrm{x}$ \\
The share of hotels beds \% & 42.5 & 38.4 & 46.08 & $\mathrm{x}$ & $\mathrm{x}$ \\
\hline
\end{tabular}

Source: Processed based on the data of Statistical Office SR, 2001, 2009 and 2017.

In the years $2000-2008$, the number of accommodation facilities increased (by 2.20). However, after 2008, this growth slow down and increased only by 1.02 times. The number of hotel-like facilities increased by 1.63 (2008/00), then only by 1.10 (2016/08). This was also reflected in the increase of the hotels capacity (by 1.19 and 1.36).

The size of hotels by number of beds ranged from 98 to 120 . The average hotel size was 107 beds, pension 31 beds (Table 2).

Table 2: Capacity and size of accommodation facilities

\begin{tabular}{|c|c|c|c|c|}
\hline Indicator & $\begin{array}{l}\text { Accommodation } \\
\text { facilities total }\end{array}$ & Hotels & Pensions & Pensions Index \\
\hline $\begin{array}{l}\text { Number of accommodation facilities } \\
2000 \\
2008 \\
2016\end{array}$ & $\begin{array}{l}1,559 \\
3,434 \\
3,489\end{array}$ & $\begin{array}{l}366 \\
596 \\
654\end{array}$ & $\begin{array}{l}216 \\
717 \\
818\end{array}$ & $\begin{array}{l}1.00 \\
3.32 \\
3.79\end{array}$ \\
\hline $\begin{array}{l}\text { Number of beds } \\
2000 \\
2008 \\
2016\end{array}$ & $\begin{array}{l}102,800 \\
151,991 \\
152,624\end{array}$ & $\begin{array}{l}43,735 \\
58,357 \\
70,321\end{array}$ & $\begin{array}{r}7,305 \\
15,289 \\
25,453\end{array}$ & $\begin{array}{l}1.00 \\
2.09 \\
1.66\end{array}$ \\
\hline $\begin{array}{l}\text { Average size (average number of beds) } \\
2000 \\
2008 \\
2016\end{array}$ & $\begin{array}{l}65.9 \\
44.2 \\
43.7\end{array}$ & $\begin{array}{r}119.5 \\
97.9 \\
107.5\end{array}$ & $\begin{array}{l}33.8 \\
21.3 \\
31.1\end{array}$ & $\begin{array}{l}\mathrm{x} \\
\mathrm{x} \\
\mathrm{x}\end{array}$ \\
\hline
\end{tabular}

Source: Processed based on the data of Statistical Office SR, 2001, 2009 and 2017.

The standard of hotel services has changed substantially (Table 3). There was an increase in the proportion of high-class hotels ( $4 *$ and $5 *$ class). While in 2000 this type of hotels provided $2.9 \%$ of beds, in 2016, it was $26.1 \%$. Middle-class hotels $\left(3^{*}\right)$ created $30.3 \%$ of beds in 2016 (in 2000 
it was $24.1 \%$ ). Substantial change has occurred in the lower-class hotels $\left(1^{*}\right.$ and $\left.2 *\right)$, which provided $16.8 \%$ of beds in 2016, while in 2000, it was $58.5 \%$. Pensions (guesthouses) become major competitors of hotels, mostly in small cities. In 2016, their share was 26.6\%, in 200014.3 $\%$. The growth of the hotels' capacity was linked with the creation of new facilities, especially in the larger cities, as well as with the improvement and reconstruction of existing hotels, especially historical objects, for example, boutique hotels.

Table 3: Capacity and structure of hotels

\begin{tabular}{|l|r|r|r|r|c|}
\hline Indicator/Year & \multicolumn{1}{|c|}{2000} & \multicolumn{1}{|c|}{2008} & \multicolumn{1}{|c|}{2016} & Index 2008/00 & Index 2016/08 \\
\hline Beds in hotels and pensions & 51,040 & 67,105 & 95,774 & 1.31 & 1.43 \\
$\quad$ hotels **** / ***** & 1,458 & 5,277 & 24,975 & 3.62 & 4.73 \\
hotels *** & 12,281 & 20,367 & 29,051 & 1.66 & 1.43 \\
hotels ** & 18,885 & 15,021 & 9,806 & 0.80 & 0.65 \\
hotels* & 11,009 & 10,986 & 6,298 & 1.00 & 0.57 \\
botels & 102 & 165 & 191 & 1.67 & 1.16 \\
pensions & 7,305 & 15,289 & 25,453 & 2.09 & 1.67 \\
\hline Structure of beds \% & & & & & \\
hotels ****/***** & 2.9 & 7.8 & 26.1 & $\mathrm{x}$ & \\
hotels *** & 24.1 & 30.4 & 30.3 & $\mathrm{x}$ & \\
hotels ** & 37.0 & 22.4 & 10.2 & $\mathrm{x}$ & \\
hotels* & 21.5 & 16.4 & 6.6 & $\mathrm{x}$ & $\mathrm{x}$ \\
botels & 0.2 & 0.2 & 0.2 & $\mathrm{x}$ & $\mathrm{x}$ \\
pensions & 14.3 & 22.8 & 26.6 & $\mathrm{x}$ & $\mathrm{x}$ \\
\hline
\end{tabular}

Source: Processed based on the data of Statistical Office SR, 2001, 2009 and 2017.

\subsection{Accommodation sector performance}

Performances of the accommodation facilities relate to at least one overnight stay. The most used indicators of accommodation sector performance are the number of tourists and the number of overnight stays in accommodation facilities (Table 4).

Table 4: Performances of accommodation sector in Slovakia

\begin{tabular}{|l|c|c|c|c|c|c|}
\hline Indicator & 2000 & Share in \% & 2008 & Share in \% & 2016 & Share in \% \\
\hline Number of tourists & 2,794 & 100.0 & 4,083 & 100.0 & 5,024 & 100.0 \\
$\quad$ Domestic & 1,741 & 63.3 & 2,316 & 56.7 & 2,997 & 59.7 \\
Foreign & 1,053 & 37.7 & 1,767 & 43.3 & 2,027 & 40.3 \\
\hline Number of overnight stays (in & & & & & & \\
thousands) & 10,541 & 100.0 & 12,464 & 100.0 & 14,138 & 100.0 \\
$\quad$ Domestic & 6,798 & 64.5 & 7,203 & 57.8 & 8,993 & 63.6 \\
$\quad$ Foreign & 3,743 & 35.5 & 5,261 & 42.2 & 5,145 & 36.4 \\
\hline Average length of stay & 3.8 & $\mathrm{x}$ & 3.1 & $\mathrm{x}$ & 2.8 & $\mathrm{x}$ \\
Domestic & 3.9 & $\mathrm{x}$ & 3.1 & $\mathrm{x}$ & 3.0 & $\mathrm{x}$ \\
Foreign & 3.6 & $\mathrm{x}$ & 3.0 & $\mathrm{x}$ & 2.5 & $\mathrm{x}$ \\
\hline
\end{tabular}

Source: Processed based on the data of Statistical Office SR, 2001, 2009 and 2017.

In 2000, almost 2.8 million tourists visited accommodation facilities in Slovakia, of which 1.7 million were domestic $(63.6 \%)$ and 1.1 million foreign tourists $(37.7 \%)$. The number of tourists increased by $46.1 \%$ to 4.08 million in 2008 . The domestic tourists contributed $56.7 \%$ and foreign $43.3 \%$. The total number of tourists increased by 1.46 times, while the number of foreign tourists grown faster (by 1.67) than a number of domestic tourists (1.33).

The average length of stay decreased from 3.8 in 2000 to 3.1 nights in 2008 . The average length of stay continued to decrease in 2016 (from 3.8 in 2000 to 3.1 in 2008 and 2.8 nights in 2016). Domestic tourists spent on average 3 nights in accommodation facilities (3.9 in 2000). Foreign 
tourist 2.5 nights (3.6 in 2000). Longer than the average length of stay was recorded by tourists from countries with visa duty (Israel 5.0; Serbia 5.2; Belarus 3.9; Bosnia and Herzegovina 3.4; Ukraine 3.3; Montenegro 3.1; Russia 2.9) and European Union (Bulgaria 3.5; Romania 3.2, Cyprus 3.2) (Statistical Office SR, 2017). For accommodation facilities, such a development of the average number of nights is not beneficial.

With the changes in the structure of Slovak accommodation sector, these services have stimulated the development of tourism at the international level. The population with high income can afford a more challenging consumption. However, consumers in Slovakia are middle and lower class and, therefore, their demand focuses on middle and lower-class hotels. This demonstrates the occupancy rate. Performances of accommodation sector in Slovakia are currently under the influence of many global trends and factors. The global economic crisis in 2008 and its consequences, and the adoption of the euro as the national currency in 2009.

\subsection{Product specialization in the hotel market}

Product specialization is one strategy a hotel can use to target specific customer market segments. Globalization and trends in the demand for tourism services have an impact also on the specialisation of the Slovak hotel market. In 2016, almost quarter (24.8\%) specialized their products on congress, wellness and spa services. This was supported by the Decree of the Ministry of Economy of the Slovak Republic No. 277/2008 Coll. establishing classification symbols for categorizing and ranking accommodation facilities (Table 5).

Table 5: Specialization of the hotels in 2016

\begin{tabular}{|l|c|r|c|r|r|r|r|}
\hline Classification & Hotels & \multicolumn{1}{c|}{$\begin{array}{c}\text { Tourists } \\
(\mathrm{K})\end{array}$} & $\begin{array}{c}\text { Overnight } \\
\text { stays (K) }\end{array}$ & $\begin{array}{c}\text { Revenue } \\
\text { (EUR K) }\end{array}$ & $\begin{array}{c}\text { Occupancy } \\
\text { rate }(\%)\end{array}$ & $\begin{array}{c}\text { Length } \\
\text { of stay }\end{array}$ & $\begin{array}{c}\text { Revenue } \\
\text { per tourist }\end{array}$ \\
\hline Mountain hotel***/* & 79 & 225.4 & 584.5 & $12,912.1$ & 29.7 & 2.6 & 57.30 \\
Congress*****/*** & 26 & 237.9 & 394.7 & $16,563.4$ & 33.7 & 1.7 & 69.60 \\
Wellness*****/*** & 24 & 152.3 & 367.3 & $12,892.3$ & 44.2 & 2.4 & 84.70 \\
Spa $* * * * * * * *$ & 17 & 103.0 & 651.4 & $15,675.6$ & 62.9 & 6.3 & 152.00 \\
Boutique*****/**** & 11 & 52.5 & 90.6 & $6,663.3$ & 42.7 & 1.7 & 126.80 \\
Apartment hotel***/* & 5 & 6.5 & 11.4 & 375.8 & 19.0 & 1.8 & 57.80 \\
\hline Hotels & 657 & $3,374.4$ & $8,230.6$ & $283,530.6$ & 32.9 & 2.5 & 84.02 \\
Pensions & 818 & 569.8 & $1,380.0$ & $28,066.0$ & 18.8 & 2.4 & 49.30 \\
\hline
\end{tabular}

Source: Processed based on the data of Statistical Office SR, 2017.

* $\mathrm{K}$ - Thousands.

The average occupancy rate of accommodation facilities was $29.3 \%$ in 2016 (Statistical Office SR, 2017), in hotels it was $32.9 \%$. The duration of stay in hotels (2.5 on average) and pensions (2.4) was low.

The highest occupancy rates were recorded in spa hotels $(62.9 \%)$ as well as the average length of stay (6.3 nights). The spa hotels recorded also the highest average revenue (152.00 EUR per tourist), which is $81 \%$ higher than the average of all hotels. The spa hotels are located in the natural spa areas, offering medical care and services under a doctor's supervision.

The important trend is the demand for wellness services focusing on health care, regeneration and mental well-being. These services become part of the current population lifestyle. The wellness hotel has a suitable sport and recreational equipment. It offers also rational food and diet possibilities. The condition is that to provide rehabilitation services, the hotel has to have a 
professionally trained staff. However, wellness services are also provided by other accommodation facilities without proper equipment and staff. The wellness hotels have $44.2 \%$ occupancy rate and rather a short duration of stay ( 2.4 nights). The average revenue was $84.7 \mathrm{EUR}$, same as the average revenue for all hotels.

A boutique hotel is situated in a historic building with architectural or artistic design and luxury equipment. It has between 10 and 100 rooms in unique settings and a smaller number of beds (53). In 2016, the boutique hotels recorded $42.7 \%$ occupancy rate with the relatively short duration of stay (1.7 nights). On the other hand, the revenues were quite high (126.80 EUR per tourist), $51 \%$ more than the average of all hotels.

Congress hotels focus on the congress events, which are usually held off-season. Most of the business meetings take place in the spring and autumn. These hotels have appropriate conference rooms that allow the variability and the technical conditions for the related services. In 2016, tourists spent in congress hotels only 1.7 nights on average. However, the occupancy rate was almost $33.7 \%$. From the congress events organized in Slovakia in 2016, almost $62 \%$ lasted one day (from 5,036 events). Almost a quarter were two-day events and $13 \%$ of events lasted three and more days. Tourists in congress hotels spent, on average, 69.60 EUR, which is even below the average revenue all hotels (by $17 \%$ ). Generally, it is said, that conference tourism has the highest revenue per one tourist. It should be taken into account, that the expenditure of the congress participants includes not only the accommodation but also expenditure on the other services in the hotel and in the destination as well. One of the factors influencing the expenditure of congress participants could be a restriction by the enterprises and organisations in recession.

Mountain hotels are located in mountain resorts and specialized in sport and recreation with the all-year opportunities. In 2016, they recorded $29.7 \%$ occupancy rate, 2.6 average duration of stay and 57.30 EUR per tourist (32\% lower than average revenue of all hotels). This may be the result of the orientation of the mountain hotels on the short winter season without the existence of additional services for year-round use.

When evaluating the average price for the accommodation of one tourist it is necessary to consider the product. It can be only the accommodation, or the wider product (package of services).

\subsection{Structure of Slovak hotel industry}

Globalization has an impact on changes in organizational structure as a result of economic factors and effort to reduce cost. The result is the creation of national and multinational hotel chains (groups) and partnerships. In Slovakia, hotels are mostly individual and there is no national hotel company (common brand name, similar characteristics and standards). These make local hotels vulnerable, especially in times of recession, when there is the pressure on the costs and the effort to "clean" the hotel market.

Currently, there is hotel company SOREA, which was established by transformation of former union recreational facilities. It has 15 hotels and 3 pensions with 4500 beds. Most of the companies usually own three or more hotels. They create an integration structure with central management but do not have chain characteristics (f.e. Tatry Mountain Resort, Trinity). Firs hotel chains in Slovakia established in the 80's. The first one was hotel Forum (1989) later Holiday Inn in Bratislava. Number of chain hotels shows Table 6. 
Table 6: Number of chained-brand hotels in Slovakia

\begin{tabular}{|c|c|c|c|}
\hline Year & Hotels & Chain hotels & Share (\%) \\
\hline 1988 & 346 & 2 & 0.58 \\
2000 & 366 & 3 & 0.82 \\
2008 & 596 & 28 & 4.70 \\
2016 & 654 & 39 & 5.96 \\
\hline
\end{tabular}

Source: Processed based on the data of Statistical Office SR, 2017; the authors, 2017.

While in 2000 there were 3 members of multinational hotel chains, in 2016, their number increased to 39 (6\% of all hotels) Most of them are located in Bratislava (20), then Pieštany (8), Smrdáky (3), Košice (2), Žilina (2), Bojnice (1), Trenčianské Teplice (1), Trnava (1) and Štrbské Pleso (1) (Table 7).

Table 7: Hotel chains in Slovakia in 2016

\begin{tabular}{|c|c|c|}
\hline Hotel company & Hotel chain & Hotel \\
\hline Accor Hotels (FRA) & $\begin{array}{l}\text { Ibis } \\
\text { Mercure }\end{array}$ & $\begin{array}{l}\text { Ibis Bratislava } \\
\text { Mercure Bratislava }\end{array}$ \\
\hline Austria Trend Hotels (AUT) & Austria Trend Hotels Pemium & Austria Trend Hotel Bratislava \\
\hline Best Western (USA) & $\begin{array}{l}\text { Best Western } \\
\text { BW Plus }\end{array}$ & $\begin{array}{l}\text { BW Hotel West Bratislava } \\
\text { BW Hotel Antares Bratislava } \\
\text { BW Hotel Roca Košice } \\
\text { BW hotel Capital Nitra } \\
\text { BW Palace Hotel Polom Žilina } \\
\text { BW Hotel Belassi Bojnice }\end{array}$ \\
\hline $\begin{array}{l}\text { Danubius Hotels Group } \\
\text { (HUN) }\end{array}$ & Spa Hotels & $\begin{array}{l}\text { Spa Hotel Balnea Grand Piešt’any } \\
\text { Spa Hotel Balnea Splendid Piešt'any } \\
\text { Spa Hotel Jalta Piešt’any } \\
\text { Spa Hotel Pro Patria Piešt’any } \\
\text { Spa Hotel Morava Smrdáky } \\
\text { Spa Hotel Cetral Smrdáky } \\
\text { Spa hotel Vietoris Smrdáky } \\
\text { Villa Berlin Piešt'any }\end{array}$ \\
\hline EuroAgentur (CZ) & EA & $\begin{array}{l}\text { EA Art Hotel William Bratislava } \\
\text { EA Hotel Praha Trenčianske Teplice }\end{array}$ \\
\hline $\begin{array}{l}\text { Falkensteiner Michaeler Tourism Group } \\
\text { (AUT) }\end{array}$ & Falkensteiner Hotels \& Residences & Falkensteiner Hotel Bratislava \\
\hline Hilton Worldwide (USA) & Duble Tree by Hilton & $\begin{array}{l}\text { Duble Tree by Hilton Košice } \\
\text { Duble Tree by Hilton Bratislava }\end{array}$ \\
\hline InterContinentl Hotels Group (UK) & $\begin{array}{l}\text { Interhotel } \\
\text { Holiday Inn/ } \\
\text { Express by Holiday Inn }\end{array}$ & $\begin{array}{l}\text { Hotel Crowne Plaza Bratislava } \\
\text { Holiday Inn Bratislava } \\
\text { Holiday Inn Žilina } \\
\text { Holiday Inn Trnava }\end{array}$ \\
\hline Kempinski Hotels (DEU) & Kempinski Hotels & $\begin{array}{l}\text { Grand Hotel Kempinski High Tatras Šrbské } \\
\text { Pleso }\end{array}$ \\
\hline Lindner Hotels \& Resorts (DEU) & Lindner Hotels \& Resorts & Lindner Gallery Bratislava \\
\hline NH Hoteles (ESP) & NH Hoteles & Gate One Bratislava \\
\hline $\begin{array}{l}\text { Rezidor Hotels Group } \\
\text { (USA) }\end{array}$ & $\begin{array}{l}\text { Park Inn } \\
\text { Radisson H\&R }\end{array}$ & $\begin{array}{l}\text { Hotel Park Inn Danube Bratislava } \\
\text { Radisson Blu Carlton Bratislava }\end{array}$ \\
\hline Small Luxury Hotels of the Worls (USA) & Small Luxury Hotels of the World & Hotel Marrol's Bratislava \\
\hline Starwoods Hotels and Resorts (USA) & $\begin{array}{l}\text { Sheraton } \\
\text { Luxury collection }\end{array}$ & $\begin{array}{l}\text { Sheraton Hotel Bratislava } \\
\text { Grand Hotel River Park Bratislava }\end{array}$ \\
\hline Vienna International Hotel(AUT) & Vienna International Hotels & Chopin Airport Bratislava \\
\hline
\end{tabular}

Source: Processed based on the data of hotel chains, 2017.

The multinational hotel companies have created a new competitive environment. This was reflected in a change in the structure of hotels in favor of higher classes and thus the standard and structure of the services provided. The hotel can be included in hotel chain (group, brand) based on 
ownership, management contracts or franchise agreements between the hotel and the owner of the hotel brand. Hotel chains have several advantages, which include a uniform design, common marketing and sales of the product on its own global distribution system, staff training, the single system of information and communication technologies and guarantee the quality of service.

After 2008, during the crisis, there was a decrease of tourists, especially in small independent hotels. To survive, small independent hotels focus on selective segments, active product distribution, partnership (destination management). The smallest impact of the crisis was on the large hotels and chain hotels, hotels with a competitive advantage, as is the localization of the product, the connection to the electronic systems of booking and the internet. Such hotels have a common marketing, better public relations and can spend more.

Hotel chains that want to establish themselves in the Slovak market are looking for hotels in the centres of major cities, attractive spa places and resorts with the possibility of all-year round use and sufficient demand. Despite the various advantages, the significant part of the independent hotels is against inclusion in the hotel chains. These hotels are part of the European culture and history, and therefore will always be interesting, unlike hotels, e.g. in North America, where the tourist is looking for just a place to overnight and the benefits of loyalty programs.

\section{Conclusion}

Globalization has a significant impact on the accommodation sector in Slovakia, especially hotel industry. The aim of this paper was to examine changes in Slovak accommodation sector in the process of globalization. The article seeks to give answers to the following questions:

(1) What changes have occurred in the structure and performance of accommodation sector before and after the global crisis (in 2000 and 2008, 2008 and 2016)? While the number of accommodation facilities increased by 2.20 times in $2000-2008$ (hotels by 1.63 ), after 2008 this trend slow down and increased only by 1.02 times. The share of hotel beds in 2000 was $42.5 \%$ on the total number of beds in accommodation sector, then dropped to $38.4 \%$ in 2008 , but increase to $46.0 \%$ in 2016 . Whereas in 2000 the share of high-class hotels $\left(4^{*}\right.$ and $5^{*}$ class) was only $2.9 \%$, in 2008 it was $7.8 \%$ and in 2016 it was $26.1 \%$. The share of lower class hotels (** and *) significantly decreased from $58.5 \%$ in 2000 to $16.8 \%$ in 2016 . Some of them have been upgraded and expanded with a range of additional services and ranked as ***. However, most often, they have been reclassified as pensions, respectively, other accommodation category. The changes in the structure of accommodation sector can be considered as favourable trend, which corresponds to current the current demand. There were also changes in terms of number of tourists, number of overnight stays and average length of stay. Despite the increase in the total number of tourists and the total number of overnight stays, after 2008 the structure changed for the benefit of domestic tourists, who in 2016 represented $59.7 \%$ of the visitors and $63.6 \%$ of the number of overnight stays. The average length of stay of domestic tourists has dropped from 3.9 in 2000 to 3.0 in 2016. More significantly, the average number of nights spent by foreign tourists dropped from 3.6 in 2000 to 2.5 in 2016. This result may be due to the lack of marketing activity of hotels, especially electronic marketing and improper use discount portals;

(2) What is the product specialization in the Slovak hotel industry? Hotels started to specialize their services and customer segments according to the Decree of the Ministry of Economy of the Slovak Republic No. 277/2008 Coll. In this way, hotels could be distinguished as a mountain, congress, wellness, spa and boutique. The higher occupancy rate reported spa hotels 
$(62.9 \%)$ and wellness and boutique hotels $(42.7-44.2 \%)$. Spa hotels have also higher revenue per guest (152.00 EUR) following boutique hotels (126.80 EUR). Product-specific hotels can improve their performance in particular through targeted marketing;

(3) How the hotel industry structure in Slovakia changed after 2000 due to the entry of multinational hotel companies? The international hotel companies started to establish themselves on the Slovak hotel market only in 1989. While in 2000 there were only 3 chained hotels, later in 2016, there were 39 hotels. These hotels are located in large towns and spa and recreational resorts with year-round demand. They offer high quality services with respect to the globalization trends and creates a competitive environment in destinations.

The capacity of the hotel industry is conditional on effective demand, which stagnates, inter alia, lack of attractive complex products. In Slovak accommodation sector, the investments are focused mainly on "hardware" e. g. construction and modernization. There is a lack of interest to improve the quality of services and provide appropriate conditions for employees (software). The success of the hotel is determined by employees and the product. It is also necessary to support the quality of the product by offensive marketing strategy, using electronic distribution and internet marketing communications. If the hotel wants to prosper in a competitive market, its management has to monitor the globalisation factors and trends and the behaviour of the customers - the guests.

\section{References}

[1] ALEJZIAK, W., 2007. Megatrendy a zmeny v rozvoji národnej a medzinárodnej politiky cestovného ruchu. Ekonomická revue cestovného ruchu, 40 (1), ISSN 0139-8660

[2] BURANOVSKÝ, J., 2011. Nákupné správanie obyvatel’ov krajín V4 ako návštevníkov v cestovnom ruchu. Ekonomická revue cestovného ruchu, 43 (4), ISSN 0139-8660

[3] GÚČIK, M., 1999. Globalizácia - hrozba i výzva pre slovenský cestovný ruch. Profesionálna príprava odborníkov pre cestovný ruch v 21. storočí. Zborník z konferencie. Editor M. Gúčik. Banská Bystrica : Univerzita Mateja Bela - Ekonomická fakulta, 1999. ISBN 80-8055-243-6.

[4] GÚČIK, M.,2009. Vplyv globalizácie na rozvoj hotelierstva v Slovenskej republike. Cestovný ruch - teória a prax v podmienkach globalizácie. Zborník z konferencie (CD- ROM). Editor M. Gúčik. Banská Bystrica : Ekonomická fakulta UMB, 2009. ISBN 978-80-8083-744-0.

[5] GÚČIK, M. a I. ŠÍPKOVÁ, 2004. Globalizácia a integrácia v cestovnom ruchu. Banská Bystrica : Dali-BB, 2004. 142 s. ISBN 80-969261-0-1.

[6] GÚČIK, M. a K. ULIČNÁ, 2014. Etablovanie siet'ových hotelov na Slovensku. Ekonomická revue cestovného ruchu, 47 (2), ISSN 0139-8660

[7] GÚČIK, M. a M. VETRÁKOVÁ, 2013. Vplyv globalizácie na spotrebné správanie návštevníkov v cestovnom ruchu. Globalizácia a jej sociálno-ekonomické dôsledky 2013. Zborník z konferencie [CD-ROM ]. Editor Š. Cisko. Žilina : Žilinská univerzita Fakulta prevádzky a ekonomiky dopravy a spojov, 2013. ISSN 1336-5878.

[8] HJALAGER, A-M. 2007. Stages in the economic globalization of tourism. Annals of tourism research, 34 (2), ISSN 0160-7383

[9] HORSKÁ, E. a I. UBREŽIOVÁ, 2001. Manažment a marketing v medzinárodnom prostredí. Nitra : SPU, 2001. 418 s. ISBN 80-7137-884-4. 
[10] KVASNOVÁ, D. a K. PANČÍKOVÁ, 2011. Vplyv globálnej hospodárskej krízy na nákupné správanie obyvatel'ov krajín V4 v cestovnom ruchu. Ekonomická revue cestovného ruchu, 49 (1), ISSN 0139-8660

[11] MINISTERSTVO DOPRAVY A VÝSTAVBY SR., 2017. Kongresový cestovný ruch 2017/2016. Sekcia cestovného ruchu, 2018.

[12] NAWROCKA, E. and S. OPARKA, 2007. Hotel w XXI wieku zarządzanie w warunkach globalizacji. Wrocław : Edukacja, 2007. 273 s. ISBN 978-83-87708-49-8.

[13] NOWAKOWSKA, A., 2006. Turystyka a proces globalizacji. Turystyka w ujęciu podmiotowym i przestrzennym. Editor G. Gołembski. Poznań : Vydawnictwo AE, 2006.

[14] SIRU゚ČEK, P. a S. HECZKO, 2006. Globalizace - vybrané teoretické aspekty. E+M Ekonomie a managemet, 6 (4), ISSN 1212-3609

[15] SMERAL, E., 1998. The impact of globalization on small and medium enterprises. New hallenges for tourism policies in European Countries. Tourism management, 19 (4), 02615177

[16] Štatistika Štatistického úradu SR, 2001, 2009, 2017.

[17] Vyhláška Ministerstva hospodárstva SR č. 277/2008 Z. z., ktorou sa ustanovujú klasifikačné znaky na ubytovacie zariadenia pri ich zarad'ovaní do kategóríi a tried. 